\title{
18. FERROMANGANESE DEPOSITS FROM THE WOMBAT PLATEAU, NORTHWEST AUSTRALIA ${ }^{1}$
}

\author{
Eric H. De Carlo² and Neville F. Exon ${ }^{3}$
}

\begin{abstract}
Ferromanganese crusts, nodules, and ferromanganese-rich sediments were recovered on the Wombat Plateau, northwest Australian continental margin, by dredging during Bureau of Mineral Resources cruise 56 of Rig Seismic and by drilling during ODP Leg 122 of JOIDES Resolution. We report here the chemistry and mineralogy of the ferromanganese crusts, nodules, and associated ferromanganese-rich sediments. The ferromanganese deposits from the ODP sites are up to $40 \mathrm{~cm}$ thick and probably formed in Late Cretaceous to Eocene times. Those from outcrops usually formed in several phases, and their age is unconstrained except that the substrates are Mesozoic. The samples were recovered from present-day water depths of $2000-4600 \mathrm{~m}$, on the Wombat Plateau adjacent to the Argo Abyssal Plain.

Both the nodules and crusts are primarily vernadite $\left(\delta-\mathrm{MnO}_{2}\right)$ and are chemically and mineralogically similar, and not dissimilar from ferromanganese deposits found elsewhere on Australian and other marginal plateaus. They are markedly different from most deep-sea deposits. The only crystalline iron phase identified within the ferromanganese deposits is goethite. Concentrations of metals of potential economic interest are generally low compared to those from vernadite-rich seamount crusts and nodules and from abyssal nodules from areas of high resource potential in the Pacific Ocean. Maximum metal values reach $0.55 \% \mathrm{Co}, 0.58 \% \mathrm{Ni}$, and $0.20 \% \mathrm{Cu}$ in deposits containing $4.8 \%$ to $30.9 \% \mathrm{Fe}$ and $4.4 \%$ to $21.1 \% \mathrm{Mn}$.
\end{abstract}

\section{INTRODUCTION}

Marine ferromanganese deposits are nearly ubiquitous in the world's oceans and occur primarily as loose nodules or as encrustations on hard substrate outcrops (Glasby, 1977). Although nodules are more common in abyssal settings and crusts are typically found on exposed surfaces of seamounts, both types of deposits are also known to coexist. Hydrothermal Fe-Mn oxides found near sites of active venting such as mid-ocean ridges and fore- and back-arc settings represent an additional form of $\mathrm{Fe}-\mathrm{Mn}$ deposit in the marine environment.

Marine Fe-Mn deposits have been a subject of great interest for several decades because they may represent a potential source of economically valuable metals such as $\mathrm{Co}$, $\mathrm{Cu}$, and $\mathrm{Ni}$. The literature is replete with papers discussing different aspects of nodule chemistry, geology, and extractive metallurgy (e.g., Glasby, 1977; Meylan et al., 1981, and references therein; Exon, 1982). More recently a renewed interest in marine minerals has led to the exploration of seamount $\mathrm{Fe}-\mathrm{Mn}$ crust deposits because these are enriched in the currently more valuable metal Co relative to their abyssal nodule counterparts. Work discussing seamount $\mathrm{Fe}-\mathrm{Mn}$ crusts includes, but is not limited to, Craig et al. (1982), Halbach et al. (1982, 1983), Halbach and Manheim (1984), Aplin and Cronan (1985a, 1985b), Hein et al. (1985a, 1985b, 1988), De Carlo et al. (1987a, 1987b), Pichoki and Hoffert (1987), and De Carlo and Fraley (1990). Summaries of nodule and crust data from the Australian region have been presented by Jones (1980) and Exon et al. (in press).

We present here the results of bulk chemical and mineralogical analyses performed on a suite of Fe-Mn oxides recovered during several expeditions of Rig Seismic and JOIDES

\footnotetext{
1 von Rad, U., Haq, B. U., et al., 1992. Proc. ODP, Sci. Results, 122 College Station, TX (Ocean Drilling Program).

2 Department of Oceanography, School of Ocean and Earth Sciences and Technology, University of Hawaii, Honolulu, HI 96822, U.S.A.

${ }^{3}$ Bureau of Mineral Resources, Canberra, ACT, 2601 Australia.
}

Resolution to the Wombat Plateau, a subplateau of the Exmouth Plateau, on the Australian Northwest Shelf.

\section{STUDY AREA AND ANALYTICAL METHODS}

\section{Regional Setting and Physical Description}

The ferromanganese deposits described here all come from the Wombat Plateau, which is a horst block on the northern margin of the Exmouth Plateau of northwestern Australia (Fig. 1). The crest of the Wombat Plateau is about $1800 \mathrm{~m}$ below sea level and forms part of the southern margin of the 5600-m-deep Argo Abyssal Plain (Exon and Willcox, 1980). It is cut off from the Exmouth Plateau proper to the south by a half-graben, where the sill water depth is about $2800 \mathrm{~m}$. The plateau is elongated east-west and the area less than $2000 \mathrm{~m}$ deep is about $100 \times 50 \mathrm{~km}$ in extent. It became a free-standing horst in the Late Jurassic, and a major wave-cut unconformity separates the Triassic and Jurassic sedimentary and volcanic rocks from the overlying Early Cretaceous age and younger sedimentary rocks. The Wombat Plateau has been surveyed geophysically by a number of vessels, and has been extensively dredged and cored by the Australian Bureau of Mineral Resources (BMR) using Sonne (von Stackelberg et al., 1980) and Rig Seismic (Exon et al., 1986) as well as drilled during Leg 122 of the Ocean Drilling Program (ODP) using JOIDES Resolution (Haq, von Rad, et al., 1990).

Manganese crusts and nodules were dredged from the northern slope of the Wombat Plateau in water depths of 4600-2800 m using Rig Seismic (Table 1). Most had formed on a substrate of Mesozoic rocks of altered volcanic or sedimentary lithology (von Rad et al., this volume). Most are crusts that vary in thickness from mere veneers to massive crusts 8 $\mathrm{cm}$ thick, from poorly to well laminated, from rough to smooth surfaced, and from mid-brown to very dark brown in color. In general these deposits are fairly pure $\mathrm{Fe}-\mathrm{Mn}$ oxides but clayey calcareous layers are present in some of them. Several generations of Fe-Mn oxide deposition are well illustrated in sample BMR56-DR14I-1. 


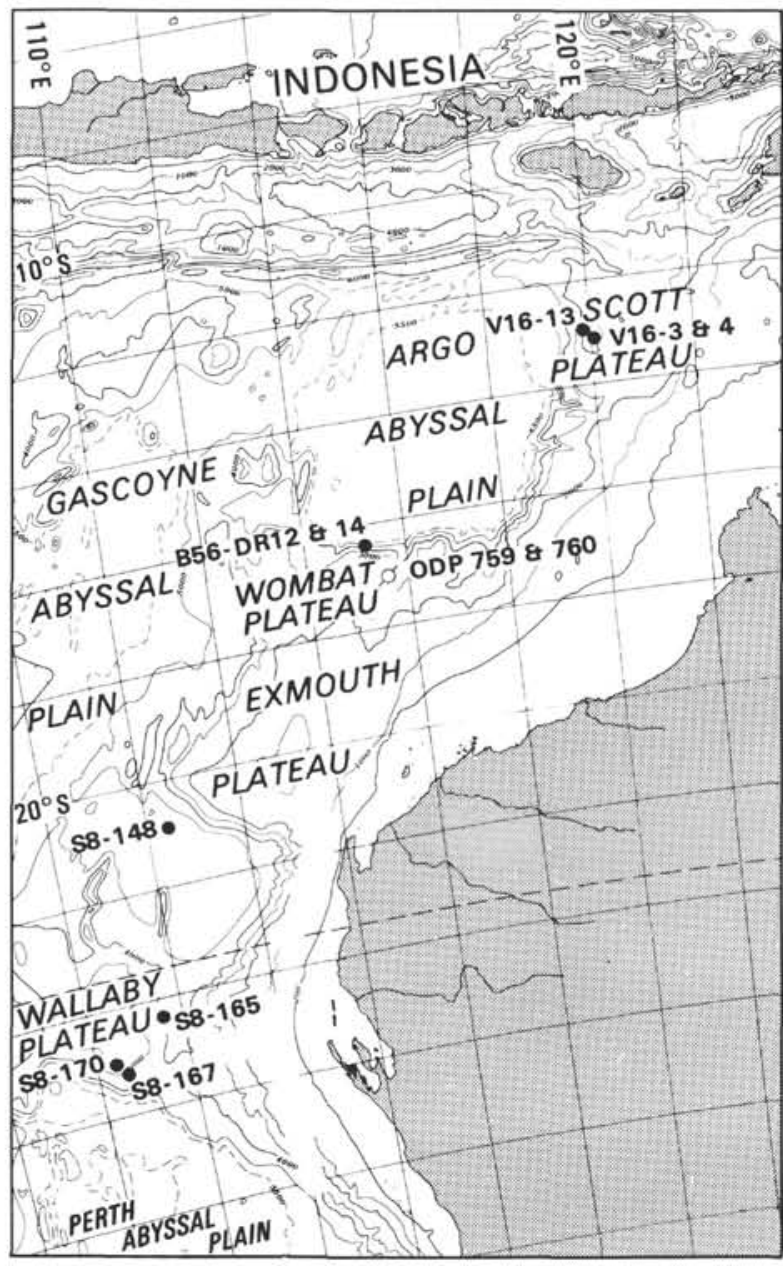

of ODP drill hole with $\mathrm{Fe}-\mathrm{Mn}$ deposits

- Fe-Mn nodules and crusts outcropping

Figure 1. Bathymetric map showing locations of ferromanganese deposits, Sites 759 and 760, and BMR dredge hauls B56-DR12 and B56-DR14 on the Wombat Plateau, Valdivia stations V16-3 and V16-4 on the Scott Plateau, and Sonne stations S8-148, S8-165, S8-167, and S8-170 on the Wallaby Plateau.

Manganese nodules and crusts were cored at Leg 122 Sites 759 and 760 on the southern slope of the Wombat Plateau (Table 1). In Section 122-759B-9R-1, a displaced nodule $3 \mathrm{~cm}$ in diameter, buried under sediment, appears to have originated from the boundary between Upper Triassic detrital sedimentary rocks and lower Miocene nannofossil ooze. At the boundary is a foraminiferal quartz sand, at least $1.4 \mathrm{~m}$ thick, containing small manganese fragments and clearly representing the onset of Cenozoic deposition after a long period of erosion or nondeposition. This indicates that the nodule formed more than $17 \mathrm{~m} . \mathrm{y}$. ago.

At Site 760 , manganese nodules, as large as $5 \mathrm{~cm}$ in diameter, and crusts occur in unfossiliferous fining-upward sequences of silty sandstone, sandy siltstone, and silty claystone, over a recovered interval $6.4 \mathrm{~m}$ thick in Core 122$760 \mathrm{~A}-9 \mathrm{H}$ (lithologic Unit III) through Core 122-760A-11X (lithologic Unit IV). These Mn-bearing strata overlie Upper Triassic marine claystone siltstone and sandstone and underlie upper Eocene nannofossil ooze. These relationships indicate that they are more than $35 \mathrm{~m}$.y. old. The strata consist of a $40-\mathrm{cm}$ nodular Mn crust on top (Section 122-760A-9H-5), a
Table 1. Ferromanganese nodules and crusts recovered from the Wombat Plateau.

\begin{tabular}{|c|c|}
\hline $\begin{array}{l}\text { Site (location; } \\
\text { water depth) }\end{array}$ & Description \\
\hline $\begin{array}{l}\text { BMR56-DR12 } \\
\left(16^{\circ} 31^{\prime} \mathrm{S}, 115^{\circ} 17^{\circ} \mathrm{E}\right. \\
4600-3500 \mathrm{~m})\end{array}$ & $\begin{array}{l}\text { All ferromanganese crusts probably formed on } \\
\text { Mesozoic volcanic rocks. Sample BMR56- } \\
\text { DR12-B2 is poorly laminated and } 6.5 \mathrm{~cm} \text { thick. } \\
\text { Sample BMR56-DR12-B3 is variably laminated } \\
\text { and } 5 \mathrm{~cm} \text { thick. The upper } 3 \mathrm{~cm} \text { of Sample } \\
\text { BMR56-DR12-B4 is laminated and the } \\
\text { structureless lower part is } 5 \mathrm{~cm} \text { thick. }\end{array}$ \\
\hline $\begin{array}{l}\text { BMR56-DR14 } \\
\left(16^{\circ} 33^{\prime} \mathrm{S}, 115^{\circ} 27^{\prime} \mathrm{E}\right. \\
3440-2690 \mathrm{~m})\end{array}$ & $\begin{array}{l}\text { The dredge haul contained Upper Triassic shelf } \\
\text { carbonates, Cretaceous mudstones, and } \\
\text { Cretaceous/Paleogene chalk. Sample } \\
\text { BMR56-DR14-I1 shows three generations of } \\
\text { growth: a 2-cm nodule/crust, a 1.5-cm-thick } \\
\text { amorphous crust, and a 1.5-cm-thick } \\
\text { botryoidal crust. Sample BMR56-DR14-I2 } \\
\text { consists of Mn crustal fragments in a matrix of } \\
\text { calcareous sandstone. Sample } \\
\text { BMR56-DR14-G1 is a 2-mm veneer around a } \\
\text { 2.5-cm-diameter claystone core. }\end{array}$ \\
\hline $\begin{array}{l}\text { ODP Site } 759 \\
\left(16^{\circ} 57^{\prime} \mathrm{S}, 115^{\circ} 34^{\prime} \mathrm{E}\right. \\
2092 \mathrm{~m})\end{array}$ & $\begin{array}{l}\text { Sample } 122-759 \mathrm{~B}-9 \mathrm{R}-1,0-3 \mathrm{~cm},(69 \mathrm{mbsf}) \text { is a } 2 \\
\times 3 \mathrm{~cm} \text { nodule with a botryoidal surface. The } \\
\text { ferromanganese portion is about } 5 \text { to } 7 \mathrm{~mm} \\
\text { thick around a large brown nucleus. } \\
\text { Ferromanganese oxide (dendritic) intergrowths } \\
\text { occur in the substrate material. The } \\
\text { substrate/crust boundary is sharp on one side } \\
\text { but more diffuse on the other. The nodule is } \\
\text { likely of pre-Oligocene age. }\end{array}$ \\
\hline $\begin{array}{l}\text { ODP Site } 760 \\
\left(16^{\circ} 55^{\prime} \mathrm{S}, 115^{\circ} 32^{\prime} \mathrm{E}\right. \\
1970 \mathrm{~m})\end{array}$ & $\begin{array}{l}\text { The samples are from a variegated } \\
\text { unfossiliferous siliciclastic sequence, } 78-84 \\
\text { mbsf, of probable Late Cretaceous to Eocene } \\
\text { age. Three samples in Section } 122-760 \mathrm{~A}-9 \mathrm{H}-5 \\
\text { are from a } 40 \text {-cm-thick nodular crust. Two } \\
\text { samples from Sections } 122-760 \mathrm{~A}-10 \mathrm{X}-1 \text { and } \\
122-760 \mathrm{~A}-11 \mathrm{X}-1 \text { are nodules from a } \\
41-\mathrm{cm} \text {-thick lower layer contained in } \\
\text { siliciclastic sediments. The nodules are slightly } \\
\text { botryoidal on the surface but generally } \\
\text { smooth. The Fe-Mn nodules are very shiny } \\
\text { and black and are surrounded by dark } \\
\text { brown-black ferromanganese oxide-enriched } \\
\text { sediment. }\end{array}$ \\
\hline
\end{tabular}

$360-\mathrm{cm}$ variegated siliciclastic layer, a 41-cm mixed layer of siliciclastic sediment and nodules (Section 122-760A-10X-1), and a $76-\mathrm{cm}$ variegated siliciclastic layer (Section $122-760 \mathrm{~A}-$ 11X-1) with an Mn nodule on top which probably fell downhole from Section 122-760A-10X-1.

Similar nodules and crusts have been dredged from the Scott Plateau, $650 \mathrm{~km}$ northeast of the Wombat Plateau (Fig. 1), and from the Wallaby Plateau, 450 to $550 \mathrm{~km}$ to the south (Hinz et al., 1978; von Stackelberg, 1978; von Stackelberg et al., 1980).

\section{Possible Age of Ferromanganese Deposits}

The Wombat Plateau sank to bathyal depths in the Late Cretaceous, with pelagic ooze and chalk predominating from middle Albian times. Until the Oligocene, when the CircumAntarctic Current developed, the west wind drift drove currents around northwestern Australia, causing widespread erosion in the deep sea, especially in the Paleocene to early Eocene and the early Oligocene (Cook, 1977). Site 765 on the Argo Abyssal Plain (Ludden, Gradstein, et al., 1990) shows four unconformities in the Cenozoic sequence. There are several unconformities produced by bathyal currents on the Wombat Plateau, and strong deep-water currents are present 
today. At Site 761, where the most complete CretaceousCenozoic section was drilled, there are unconformities between the late Neocomian to Aptian, early Eocene, late Eocene to early Oligocene, late Miocene, and early to middle Pliocene, corresponding fairly closely to the results from Site 765 on the abyssal plain.

Ferromanganese nodules and crusts can form at any unconformity, so on the Wombat Plateau the possibilities for formation are great. The general opinion arising from the ODP results is that the Wombat Plateau was subject to sedimentation during most of the Jurassic and erosion in the Late Jurassic, so manganese deposits are unlikely to be older than Late Jurassic. This suggests that the deposits at Site 760 formed sometime in the Cretaceous-Eocene period and those at Site 759 sometime in the Cretaceous-Oligocene. Indeed, microscopic examination of foraminifers attached to or incorporated in Samples 122-760A-9H-5, 2-4 cm, and 122-759B$9 \mathrm{R}-1,0-3 \mathrm{~cm}$, corroborate and refine these suggestions. Well-preserved spiny-walled forms characteristic of the Eocene (e.g., Acarinina primitiva, A. soldadoensis gr.) were observed in the former sample and are interpreted as from the early Eocene (J. Resig, unpubl. data, 1989). Foraminifers in the latter sample are not as well preserved, but are also suggestive of late Paleocene or Eocene organisms. It is also possible that these foraminifers represent downhole contamination (von Rad et al., this volume), and, hence, represent a minimum age. Calcispheres in the sand directly underlying the manganese crusts at Site 760 (in Sections 122-760A-9H-6 and $122-760 \mathrm{~A}-10 \mathrm{X}-1$ ) have been tentatively dated as (Early) Cretaceous (H. Keupp, pers. comm. to U. von Rad, 1990); hence, it is likely that the manganese crust is of Late Cretaceous to Eocene age.

The dredged ferromanganese material from the submarine outcrops (samples BMR56-DR12 and BMR56-DR14) also generally has formed on Mesozoic substrates. The ferromanganese includes very well-preserved arenaceous foraminifers (Fig. 2) that cannot be identified. The substrates on which the crusts formed were probably deeply buried at least until continental breakup formed the Argo Abyssal Plain in the earliest Cretaceous. Bathyal sedimentation started in the Aptian, so that is probably the earliest possible age for onset of nodule and crust formation. It is highly likely that such formation has continued at suitable locations until the present day.

\section{Analytical Procedures}

Selected representative specimens were separated from attached foreign or substrate material, subsampled, and examined under a binocular microscope. Air-dried portions of the material of interest were manually ground to pass SPEX standard 100 -mesh sieves and stored in glass vials for subsequent work.

The mineralogy was studied with X-ray diffraction (XRD), using a Scintag PAD-V diffractometer equipped with CuK radiation and a solid-state $\mathrm{Ge}-\mathrm{Li}$ detector. Samples were analyzed as dried slurries on glass slides. Samples were scanned at a rate of $2^{\circ} 2 \mathrm{\theta} / \mathrm{min}$ over the range of $2^{\circ}-70^{\circ}$.

Chemical analyses were performed on a $110^{\circ} \mathrm{C}$ dry basis. Duplicate or triplicate splits of each sample were dissolved with mineral acids in a microwave oven using CEM Corporation Teflon digestion vessels. The microwave technique, adapted after Nadkarni (1984) and Kingston and Jassie (1986), is much more efficient than either open-vessel digestion or bomb digestion in an induction oven and requires less reagent and only about $15 \mathrm{~min}$ of digestion as compared with several hours for the former methods. Digestion of the samples was performed with $\mathrm{HCl}, \mathrm{HNO}_{3}$, and $\mathrm{HF}$ to ensure complete solubilization of the aluminosilicate fraction. Two ferromanganese-rich sediment samples from Site 760 that contained a large proportion of $\mathrm{CaCO}_{3}$ were pretreated prior to further analysis. Carbonate removal was performed by a mildly corrosive leach in a pH 5.0 sodium acetate and acetic acid buffer. Rare earth elements (REE) were separated from major and minor constituents by ion-exchange chromatography prior to analysis as described by De Carlo (1990). Elemental analysis was performed by inductively coupled plasma (ICP) emission spectroscopy using a Leeman Labs Plasma Spec I sequential ICP system. The relative precision of replicate determinations was generally better than $5 \%$ of the reported value; accuracy was ascertained to be within $5 \%$ relative by analysis of U.S. Geological Survey standard Fe-Mn nodules A-1 and P-1 (Flanagan and Gottfried, 1980).

\section{RESULTS AND DISCUSSION}

\section{Mineralogy}

A compilation of crust, nodule, and sediment mineralogy is given in Table 2. The identification of mineral phases is based on peak positions and relative intensities as compared to standard reference patterns.

The manganese oxide phases found in this study are limited to vernadite $\left(\delta-\mathrm{MnO}_{2}\right)$ and todorokite. Vernadite is identified by two broad peaks at 2.45 and $1.42 \AA$ (Burns and Burns, 1977; Ostwald, 1988), and represents hydrogenetic manganese oxide precipitated under oxidizing conditions. Todorokite, identified on the basis of reflections at 9.6, 4.8, and 3.2 $\AA$ (Ostwald, 1988), was observed only in the upper part of dredge sample BMR56DR12-B2, but was common in the ODP samples (six out of eight); in all cases, however, the amount of todorokite present is quite small relative to that of vernadite. The macroscopic morphology of the todorokite-bearing samples is similar to that of the vernadite crusts, which suggests that the deposition of the principal phase, vernadite, took place under oxidizing conditions but likely also was influenced by secondary diagenetic interactions that led to the formation of todorokite. It is also possible that the todorokite formed as a result of postdepositional reworking of the deposits. A mixture of vernadite and todorokite is common in abyssal nodules found at the sediment/seawater interface; the seawater-exposed surface is more enriched in vernadite, whereas the bottom half of the nodule, buried in the sediment, is enriched in todorokite (Bolton et al., 1990, and references therein).

Goethite is the only crystalline Fe oxide phase found in this study. Its principal reflections occur at 4.19, 2.69, 2.45, 2.19, and $1.72 \AA$. Goethite was observed in the lower part of sample BMR56-DR12-B2, Sample 122-760A-10X-1, 14-16 cm, and the inner and outer sections of Sample 122-760A-11X-1, 7-9 $\mathrm{cm}$. Sample BMR56-DR12-B2 contains significantly more goethite than the others. Most marine ferromanganese oxides usually contain X-ray amorphous $\mathrm{FeOOH}$, but the occurrence of goethite has been reported in samples where the vernadite structure cannot incorporate all the $\mathrm{Fe}$ within the interlayers of the $\mathrm{MnO}_{2}$ (D. S. Cronan, pers. comm., 1989). Von Stackelberg et al. (1984) and, more recently, De Carlo (1991) have reported the presence of goethite in certain layers of deep-sea hydrogenous crusts.

The majority of the samples also contain detrital material (quartz, feldspars, and clay minerals) as well as calcite. Calcite is a primary constituent of sample BMR56-DR14-I2, a ferromanganese-impregnated carbonate rock substrate with a thin outside coating of $\mathrm{Fe}$ and $\mathrm{Mn}$ oxides. Calcite is also abundant in the ferromanganese oxide-bearing sediments recovered at Site 760 . The latter also contain a significant amount of quartz. 
A

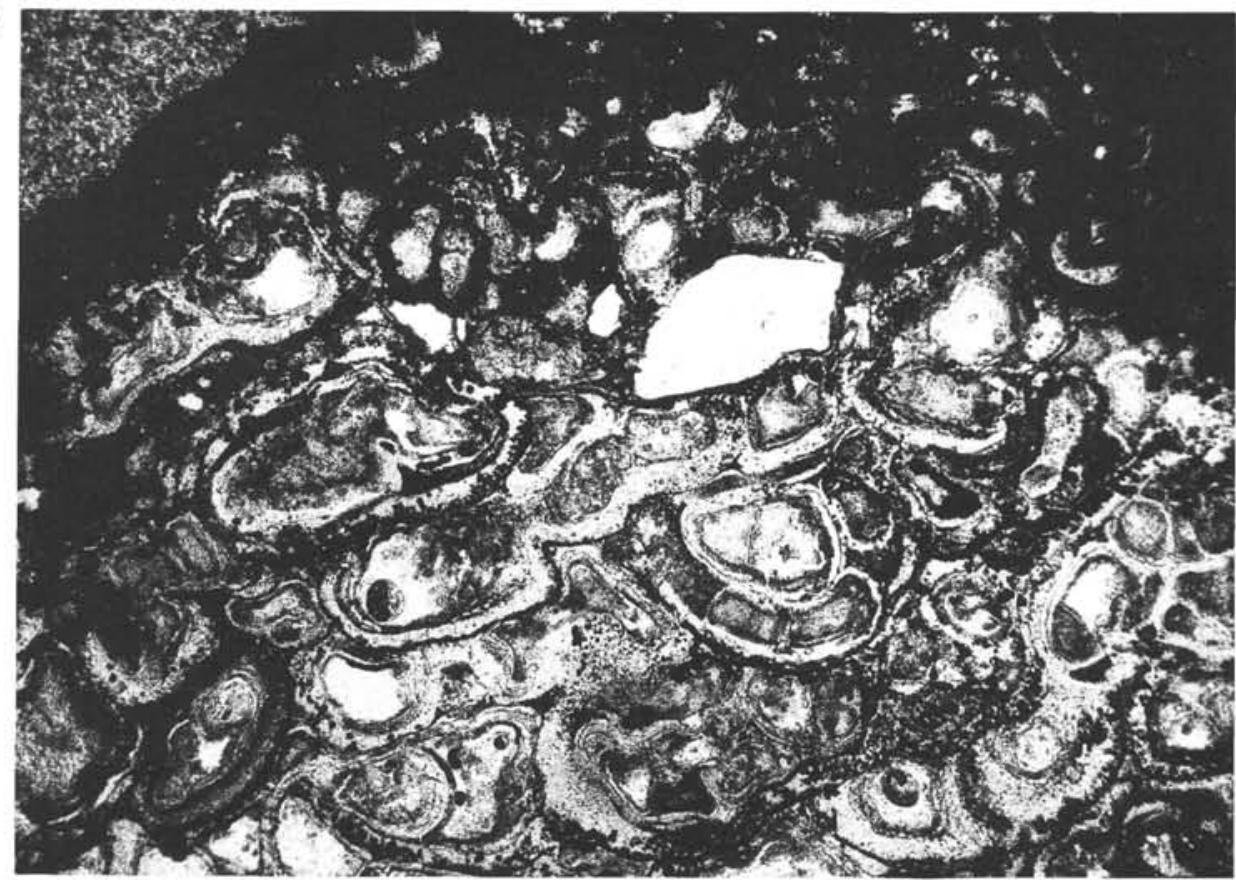

B

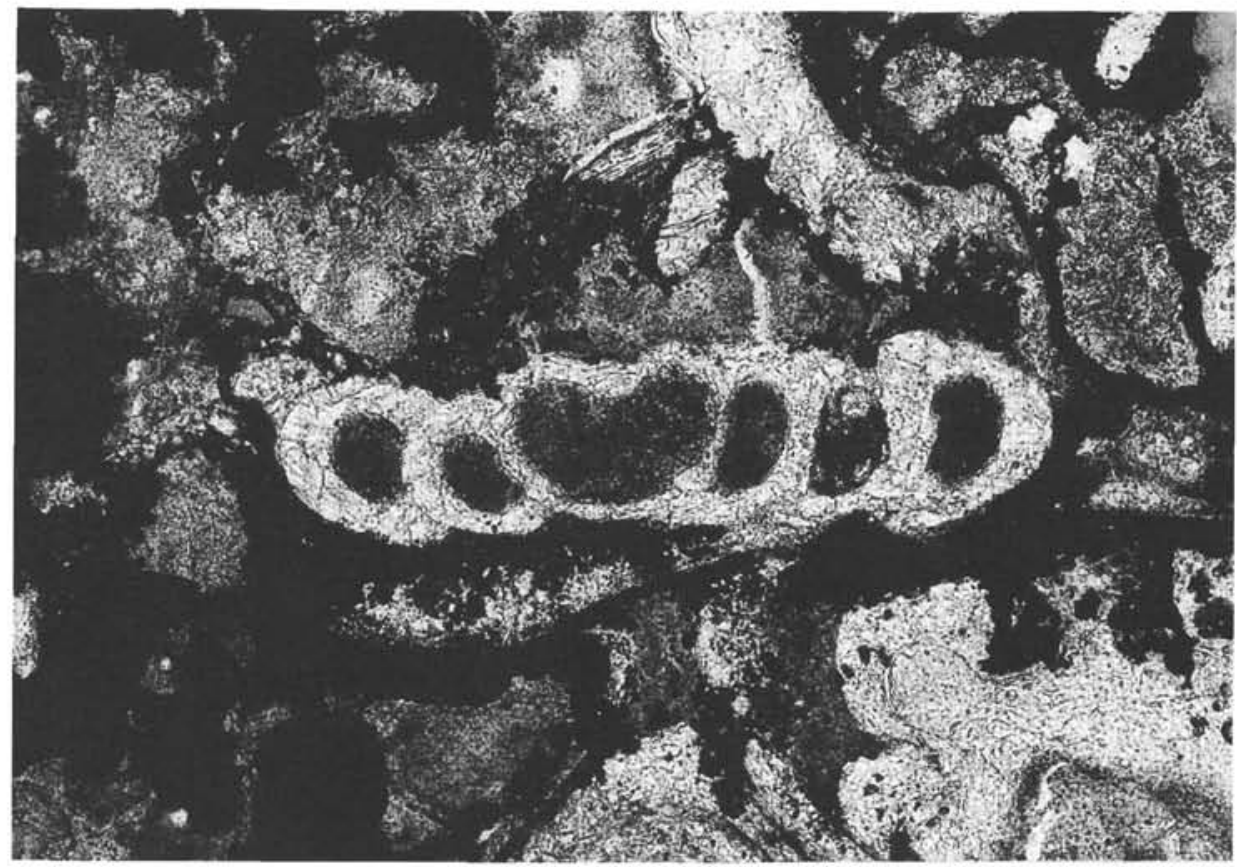

Figure 2. Arenaceous foraminifers in ferromanganese crusts on volcaniclastic rock from BMR station 56-DR12. A. Chambers of several individuals cut in random directions. B. Planispiral form cut normal to plane of coiling. Width of photographs is $600 \mu \mathrm{m}$.

\section{Chemical Composition}

\section{Major and Minor Elements}

The major and minor element composition of the samples analyzed in this study is presented in Table 3 . Most samples have a similar overall composition except for sample BMR56DR14-I2, which was described previously as composed primarily of calcite with traces of iron and manganese carbonates and a patchy Fe-Mn oxide surface coating. Excluding sample BMR56-DR14-I2, Fe concentrations range from $14.0 \%$ to
$30.9 \%$. A greater variability is observed in the dredged material than in the core samples, which display a range of $16.8 \%$ to $25.8 \%$. Manganese content varies between $13.2 \%$ and $21.0 \%$, excluding sample BMR56-DR14-I2 (4.4\% Mn).

All samples contain relatively low concentrations of the metals of potential economic interest. Cobalt and nickel concentrations are lowest in sample BMR56-DR14-I2 $(0.1 \%$ and $0.14 \%$, respectively). Other samples vary from $0.12 \%$ and $0.14 \%$ to maxima of $0.55 \%$ and $0.58 \%$, respectively, in Sample $122-760 \mathrm{~A}-10 \mathrm{X}-1,14-16 \mathrm{~cm}$, which consists of only a thin $(<5$ 
Table 2. Mineralogy of ferromanganese nodules and crusts from the Wombat Plateau, determined by powder XRD.

\begin{tabular}{|c|c|c|}
\hline Sample & Major & Minor or trace \\
\hline \multicolumn{3}{|l|}{ BMR56- } \\
\hline $\begin{array}{r}\text { DR12-B2 } \\
\text { (upper) }\end{array}$ & $\delta-\mathrm{MnO}_{2}$ & $\begin{array}{l}\text { Goethite, todorokite, } \\
\text { siderite }\end{array}$ \\
\hline $\begin{array}{r}\text { DR12-B2 } \\
\text { (lower) }\end{array}$ & $\begin{array}{l}\delta-\mathrm{MnO}_{2}, \\
\text { goethite }\end{array}$ & \\
\hline DR12-B3 & $\delta-\mathrm{MnO}_{2}$ & Quartz, rhodochrosite \\
\hline $\begin{array}{r}\text { DR12-B4 } \\
\text { (upper) }\end{array}$ & $\delta-\mathrm{MnO}_{2}$ & Siderite, quartz \\
\hline $\begin{array}{r}\text { DR12-B4 } \\
\text { (lower) }\end{array}$ & $\delta-\mathrm{MnO}_{2}$ & Quartz, goethite, siderite \\
\hline DR14-G1 & $\delta-\mathrm{MnO}_{2}$, quartz & \\
\hline DR14-I1 & $\delta-\mathrm{MnO}_{2}$, quartz & $\mathrm{CaCO}_{3}$, siderite, goethite \\
\hline DR14-I2 & $\begin{array}{l}\mathrm{CaCO}_{3}, \text { siderite, } \\
\text { rhodochrosite }\end{array}$ & $\delta-\mathrm{MnO}_{2}$ \\
\hline \multicolumn{3}{|l|}{ 122-759B- } \\
\hline $\begin{array}{l}\text { 9R-1, 0-3 } \\
\mathrm{cm} \text { (nodule) }\end{array}$ & $\delta-\mathrm{MnO}_{2}$ & Quartz, siderite, goethite \\
\hline \multicolumn{3}{|l|}{$122-760 \mathrm{~A}-$} \\
\hline $\begin{array}{l}9 \mathrm{H}-5,2-4 \mathrm{~cm} \\
\text { (nodule) }\end{array}$ & $\delta-\mathrm{MnO}_{2}$ & $\begin{array}{l}\text { Quartz, } \mathrm{CaCO}_{3} \text {, todorokite, } \\
\text { siderite }\end{array}$ \\
\hline $\begin{array}{l}\text { 9H-5, 10-13 } \\
\mathrm{cm} \\
\text { (sediment) }\end{array}$ & $\begin{array}{c}\delta-\mathrm{MnO}_{2}, \text { quartz, } \\
\underset{\mathrm{CaCO}_{3}}{ }\end{array}$ & Siderite, todorokite \\
\hline $\begin{array}{l}9 \mathrm{H}-5,10-13 \\
\mathrm{~cm} \text { (nodule) }\end{array}$ & $\begin{array}{l}\delta-\mathrm{MnO}_{2}, \text { quartz, } \\
\mathrm{CaCO}_{3}\end{array}$ & Siderite, illite, clinoptilolite \\
\hline $\begin{array}{l}\text { 9H-5, 20-22 } \\
\mathrm{cm} \\
\text { (sediment) }\end{array}$ & $\begin{array}{l}\mathrm{CaCO}_{3}, 8-\mathrm{MnO}_{2}, \\
\text { quartz }\end{array}$ & Siderite, todorokite \\
\hline $\begin{array}{l}10 \mathrm{X}-1,14-16 \\
\mathrm{~cm} \text { (nodule) }\end{array}$ & $\delta-\mathrm{MnO}_{2}$, quartz & Todorokite, feldspars \\
\hline $\begin{array}{l}11 \mathrm{X}-1,7-9 \mathrm{~cm} \\
\text { (outer } \\
\text { nodule) }\end{array}$ & $\begin{array}{l}8-\mathrm{MnO}_{2}, \\
\text { goethite, } \\
\text { quartz }\end{array}$ & Siderite, todorokite \\
\hline $\begin{array}{l}11 \mathrm{X}-1,7-9 \mathrm{~cm} \\
\text { (inner } \\
\text { nodule) }\end{array}$ & $\begin{array}{l}\delta-\mathrm{MnO}_{2}, \\
\text { goethite, } \\
\text { quartz }\end{array}$ & $\begin{array}{l}\text { Siderite, todorokite, } \\
\text { feldspars }\end{array}$ \\
\hline
\end{tabular}

$\mathrm{mm}$ ) encrustation around a siliceous substrate. The two highest $\mathrm{Ni}$ and $\mathrm{Co}$ concentrations are observed in the ODP nodule samples, whereas the unconsolidated ferromanganese-rich sediments display lower concentrations of these elements (Fig. 3). Copper ranges from $0.07 \%$ to a maximum of $0.2 \%$ on a dry-weight basis. The data in this study indicate that ferromanganese oxides from the Wombat Plateau probably are of no economic interest.

Concentrations of $\mathrm{Ca}, \mathrm{Mg}$, and $\mathrm{Ba}$ are generally quite similar in all samples and lie in a relatively narrow range. Calcium values range from $0.63 \%$ to $2.65 \%$ excluding carbonate-rich Sample BMR56-DR14-I2 (23.7\%), whereas Mg and $\mathrm{Ba}$ are $0.64 \%-1.3 \%$ and $0.09 \%-0.47 \%$, respectively. A slight enrichment of $\mathrm{Ba}$ is observed in the core samples relative to the dredged material.

Concentrations of $\mathrm{Al}$ and $\mathrm{Si}$ in the Wombat $\mathrm{Fe}-\mathrm{Mn}$ oxides reflect the varying amounts of detrital quartz and aluminosilicates in the deposits. Silicon concentrations range from values of $3.7 \%$ to $13.4 \%$, whereas $\mathrm{Al}$ concentrations range from $1.1 \%$ to $3.5 \%$. Samples with greater amounts of quartz (as determined by XRD in samples BMR56-DR14-I1 and BMR56-DR14-I2) have the highest $\mathrm{Si}$ concentrations and exhibit $\mathrm{Si}: \mathrm{Al}$ ratios significantly higher than the approximately $3: 1$ ratio commonly observed for detrital alumino-silicates. Titanium concentrations range from $0.34 \%$ to $1.15 \%$. Vanadium concentrations are on the order of several hundred parts per million and range from 190 to $980 \mathrm{ppm}$. The Mo content of the Wombat Fe-Mn oxide samples is generally low, but varies by more than an order of magnitude (50-630 ppm); this metal is generally more abundant in the dredged samples than in the core samples.

The greater degree of compositional homogeneity evident in the core samples relative to the dredged $\mathrm{Fe}-\mathrm{Mn}$ material is not entirely surprising, as the former were all recovered from a much more stratigraphically and geographically constrained area. However, the finding that the concentration ranges of most elements studied are similar in both the dredged samples and the core samples would suggest that these samples formed under similar depositional (e.g., generally highly oxic) conditions. This suggests that, in a very broad sense, depositional conditions conducive to the formation of ferromanganese deposits existing over the Wombat Plateau may not have changed very much over the last $30-40 \mathrm{~m}$.y. The most notable differences in elemental abundance between samples collected by dredging and the ferromanganese layers drilled during Leg 122 lie in the generally greater $\mathrm{Ba}, \mathrm{Co}, \mathrm{Fe}$, and $\mathrm{Ni}$ abundances in the latter. An opposite trend is observed for Mo, which is more enriched in the dredged samples. The compositional differences in these elements could perhaps be related to a gradual deepening of the area since the Neocomian and/or to changes in the water temperature due to post-Eocene global cooling, although the latter would be counteracted in part by Australia's movement into subtropical regions since breakup with Antarctica. Predominating currents at the time when deposition of the cored Fe-Mn oxides began were affected by the west wind drift, which drove currents around northwestern Australia. These waters were likely enriched in nutrients and possibly trace elements, and thus local upwelling may have caused higher productivity by providing a source of elements to the accumulating Fe-Mn deposits. It is also likely that as bottom-water circulation changed as a result of the evolving geologic environment of the Wombat Plateau, waters with slightly different compositions influenced the formation of the dredged deposits (which continue to accrete to this day) and may have contributed to their slightly different compositions.

\section{Interelement Correlations}

Interelement correlations for the 16 samples from this study were calculated in a matrix containing 14 variables. The data set was also divided into two subsets representing the dredged samples and those recovered by coring in order to evaluate relationships within each group. Because of the small number of samples analyzed, use of the correlation matrices to evaluate interelement relationships should be made with caution.

The following positive correlations, in decreasing order, were found for the entire data set: $(r>0.8) \mathrm{Fe}$ with $\mathrm{V}$, and $\mathrm{Co}$ with $\mathrm{Ni}$ and $\mathrm{Zn} ;(r>0.7) \mathrm{Zn}$ with $\mathrm{Cu}$, and $\mathrm{Ba}$ with $\mathrm{Ni}$ and $\mathrm{Al}$; and $(r>0.6) \mathrm{Mg}$ with $\mathrm{Mn}, \mathrm{Co}$ with $\mathrm{Al}$ and $\mathrm{Ba}$, and $\mathrm{Zn}$ with $\mathrm{Al}$ and V. All other positive correlations display $r$ values less than $0.6(\mathrm{Co}, \mathrm{Mo}$, and $\mathrm{Ni}$ with $\mathrm{Mn}$; $\mathrm{Cu}$ and $\mathrm{Zn}$ with $\mathrm{Fe} ; \mathrm{Ba}$ with $\mathrm{Ti}$; and $\mathrm{Mg}$ with $\mathrm{Ni}$ ).

Strong negative correlations $(r>-0.7)$ are observed between $\mathrm{Ca}$ and the three metals $\mathrm{Fe}, \mathrm{Mn}$, and $\mathrm{V}$. These correlations likely result from the diluting effect of $\mathrm{CaCO}_{3}$ on the Fe-Mn fraction in the deposits (Halbach and Puteanus, 1984). Slightly weaker negative correlations between Mo and $\mathrm{Al}(r=-0.698)$ and between $\mathrm{Zn}$ and $\mathrm{Ca}(r=-0.627)$ suggest that both $\mathrm{Mo}$ and $\mathrm{Zn}$ are associated with the Fe-Mn oxide phase of the deposits, although neither shows strong correlations with $\mathrm{Fe}$ or Mn. Most interelement correlations found in this sample set are in accordance with associations previously observed in marine $\mathrm{Fe}-\mathrm{Mn}$ deposits. A somewhat surprising association is that of $\mathrm{Ba}$ with $\mathrm{Al}$ because the former is also correlated with $\mathrm{Co}$ and $\mathrm{Zn}$. 
Table 3. Major and minor element composition of selected ferromanganese nodules and crusts.

\begin{tabular}{|c|c|c|c|c|c|c|c|c|c|c|c|c|c|c|c|}
\hline Sample & $\mathrm{Fe}$ & Mn & $\mathrm{Mn} / \mathrm{Fe}$ & Co & $\mathrm{Ni}$ & $\mathrm{Cu}$ & $\mathrm{Zn}$ & $\mathrm{Ca}$ & $\mathrm{Mg}$ & $\mathrm{Ba}$ & $\mathrm{Si}$ & Al & $\mathrm{Ti}$ & V & Mo \\
\hline \multicolumn{16}{|l|}{ BMR56- } \\
\hline DR12-B2 (upper) & 19.72 & 20.65 & 1.047 & 0.319 & 0.362 & 0.070 & 0.061 & 2.08 & 1.07 & 0.103 & 5.32 & 1.36 & 0.761 & 0.071 & 0.043 \\
\hline DR12-B2 (lower) & 30.87 & 13.25 & 0.429 & 0.232 & 0.160 & 0.200 & 0.079 & 1.48 & 0.953 & 0.238 & 3.66 & 1.65 & 0.910 & 0.098 & 0.037 \\
\hline DR12-B3 (bulk) & 20.33 & 16.20 & 0.797 & 0.166 & 0.221 & 0.112 & 0.050 & 1.66 & 0.970 & 0.119 & 8.51 & 1.55 & 0.461 & 0.069 & 0.053 \\
\hline DR12-B4 (upper) & 21.21 & 21.04 & 0.992 & 0.200 & 0.339 & 0.072 & 0.061 & 2.21 & 1.09 & 0.109 & 4.59 & 1.14 & 0.612 & 0.083 & 0.063 \\
\hline DR12-B4 (lower) & 19.11 & 15.38 & 0.805 & 0.262 & 0.217 & 0.070 & 0.057 & 1.49 & 0.915 & 0.269 & 8.08 & 2.50 & 1.153 & 0.070 & 0.042 \\
\hline DR14-G1 & 14.24 & 14.44 & 1.014 & 0.124 & 0.250 & 0.076 & 0.051 & 2.28 & 0.960 & 0.086 & 9.78 & 2.09 & 0.483 & 0.059 & 0.027 \\
\hline DR14-I1 (bulk) & 13.96 & 14.74 & 1.056 & 0.318 & 0.315 & 0.168 & 0.063 & 1.81 & 0.969 & 0.119 & 13.4 & 1.36 & 0.456 & 0.069 & 0.045 \\
\hline DR14-I2 & 4.87 & 4.41 & 0.905 & 0.057 & 0.139 & 0.028 & 0.024 & 23.7 & 0.636 & 0.027 & 6.02 & 2.01 & 0.342 & 0.019 & 0.005 \\
\hline${ }^{\text {a }}$ Average & 19.92 & 16.52 & 0.881 & 0.232 & 0.266 & 0.110 & 0.060 & 1.85 & 0.987 & 0.149 & 7.62 & 1.66 & 0.690 & 0.074 & 0.044 \\
\hline Standard deviation & 5.63 & 3.08 & 0.195 & 0.074 & 0.074 & 0.054 & 0.010 & 0.33 & 0.067 & 0.073 & 3.40 & 0.48 & 0.266 & 0.013 & 0.011 \\
\hline \multicolumn{16}{|l|}{ 122-759B- } \\
\hline $\begin{array}{l}\text { 9R-1, 0-3 cm } \\
\text { (nodule) }\end{array}$ & 17.70 & 16.42 & 0.928 & 0.353 & 0.351 & 0.111 & 0.080 & 1.75 & 0.899 & 0.219 & 8.89 & 3.12 & 0.815 & 0.086 & 0.037 \\
\hline \multicolumn{16}{|l|}{$122-760 \mathrm{~A}-$} \\
\hline $9 \mathrm{H}-5,2-4 \mathrm{~cm}$ & 18.86 & 15.76 & 0.836 & 0.465 & 0.578 & 0.185 & 0.109 & 1.32 & 1.28 & 0.329 & 7.73 & 3.54 & 0.543 & 0.077 & 0.013 \\
\hline$b_{9 H}-5,10-13 \mathrm{~cm}$ & 25.84 & 13.15 & 0.509 & 0.276 & 0.297 & 0.131 & 0.098 & 0.63 & 0.786 & 0.292 & 8.94 & 2.74 & 0.696 & 0.099 & 0.010 \\
\hline $\begin{array}{l}9 \mathrm{H}-5,10-13 \mathrm{~cm} \\
\text { (nodule) }\end{array}$ & 22.29 & 13.55 & 0.608 & 0.325 & 0.346 & 0.131 & 0.086 & 2.65 & 0.836 & 0.341 & 7.52 & 2.62 & 0.689 & 0.089 & 0.007 \\
\hline $\mathrm{b}_{9 \mathrm{H}-5,20-22 \mathrm{~cm}}$ & 20.88 & 14.22 & 0.681 & 0.330 & 0.309 & 0.119 & 0.080 & 2.26 & 0.836 & 0.467 & 9.28 & 3.22 & 0.761 & 0.075 & 0.008 \\
\hline $\begin{array}{l}10 \mathrm{X}-1,14-16 \mathrm{~cm} \\
\text { (nodule) }\end{array}$ & 16.84 & 16.30 & 0.968 & 0.548 & 0.575 & 0.159 & 0.099 & 1.65 & 1.09 & 0.272 & 8.52 & 3.25 & 0.793 & 0.053 & 0.012 \\
\hline $\begin{array}{c}\mathrm{c}_{11 \mathrm{X}-1,7-9} \mathrm{~cm} \\
\text { (outer) }\end{array}$ & 22.99 & 13.94 & 0.606 & 0.325 & 0.304 & 0.116 & 0.087 & 0.88 & 0.714 & 0.308 & 9.66 & 2.48 & 0.758 & 0.092 & 0.005 \\
\hline $\begin{array}{l}\mathrm{c}_{11} \mathrm{X}-1,7-9 \mathrm{~cm} \\
\text { (inner) }\end{array}$ & 22.02 & 17.17 & 0.780 & 0.496 & 0.459 & 0.085 & 0.084 & 1.03 & 0.793 & 0.275 & 6.35 & 2.66 & 1.021 & 0.075 & 0.013 \\
\hline Average & 20.93 & 15.06 & 0.740 & 0.390 & 0.402 & 0.130 & 0.090 & 1.52 & 0.904 & 0.313 & 8.36 & 2.95 & 0.760 & 0.081 & 0.013 \\
\hline Standard deviation & 3.00 & 1.52 & 0.165 & 0.099 & 0.119 & 0.031 & 0.010 & 0.69 & 0.188 & 0.073 & 1.09 & 0.38 & 0.135 & 0.014 & 0.010 \\
\hline
\end{tabular}

Note: All sample concentrations expressed in weight percent on $110^{\circ} \mathrm{C}$ dried basis.

a Calculated excluding Sample BMR56-DR14-I2.

b Sediment from interval treated with $\mathrm{pH}=5$ buffer for carbonate removal.

${ }^{c}$ Nodule was separated into its outer and inner portions.

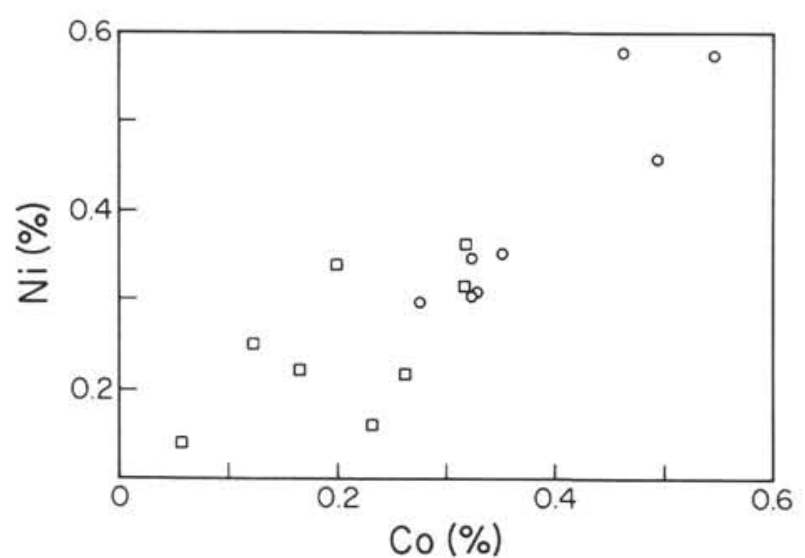

Figure 3. Scatter diagram of Co (\%) vs. $\mathrm{Ni}(\%)$ in Wombat Plateau Fe-Mn deposits. Squares $=$ BMR dredged samples; circles $=$ ODP core samples.

Breakup of the data into subsets (see Fig. 4) reveals intragroup relationships that are not immediately apparent in the composite data set. It also allows us to compare the two sample groups and better identify differences between them. This approach reveals that although the two sample groups are similar in their chemistry, they are generally distinguishable through their respective elemental compositions (Figs. 4A$4 \mathrm{~F})$. For example, there appears to be no relation between $\mathrm{Al}$ and $\mathrm{Fe}$ for the dredged samples, whereas the core samples display a strong inverse correlation between these elements
(Fig. 4A). A notable exception to this trend is the good linear relation between $\mathrm{V}$ and $\mathrm{Fe}$ for the entire sample set (Fig. 4E), although the dredged samples contain less $\mathrm{V}$ than the core samples. Positive correlations between $\mathrm{Ni}$ and $\mathrm{Mg}(r=0.783$ and 0.852 ) in each subgroup (Fig. 4F) are stronger than in the combined data $(r=0.558)$ and stronger than that reported by Hein et al. (1988) for Fe-Mn crusts from the Marshall Islands. However, the correlations contrast with observations in the Hawaiian Archipelago (De Carlo et al., 1987a), where these elements display no interdependence. These findings suggest a variability in the processes that influence the supply of $\mathrm{Ni}$ to the various areas. There may also be a small detrital input of $\mathrm{Ni}$ (from enrichment in volcanic Mg-silicates) in the Wombat samples as observed by Hein et al. (1988) in crusts from the Marshall Islands. On the other hand, $\mathrm{Ni}$ in Hawaiian crusts is primarily of hydrogenetic origin (De Carlo et al., 1987a).

Bolton et al. (1990) found a correlation between $\mathrm{Ti}$ and $\mathrm{Fe}$ in abyssal nodules $(r=0.99)$ that is much stronger than observed here $(r<0.63)$. This may result from an enrichment of $\mathrm{TiO}_{2}$ in the interlayer $\mathrm{FeOOH}$ of vernadite in smooth abyssal nodules (Halbach and Ozkara, 1979). The Ti in samples from this study is more strongly associated with $\mathrm{Fe}$ than $\mathrm{Mn}$ in the dredged samples, whereas the opposite is true in the core samples.

The associations of $\mathrm{Co}, \mathrm{Ni}, \mathrm{V}$, and Mo with $\mathrm{Mn}$ are generally stronger in the dredged subset matrix, reflect the influence of depth-dependent hydrogenetic enrichment processes (Halbach and Puteanus, 1984), and are consistent with other studies (Aplin and Cronan, 1985a; Halbach et al., 1982; Hein et al., 1985b, 1988; De Carlo et al., 1987a, 1987b). Figure 3 also shows that $\mathrm{Co}$ and $\mathrm{Ni}$ are strongly associated with each other, with slightly more scatter observed in the dredged data 

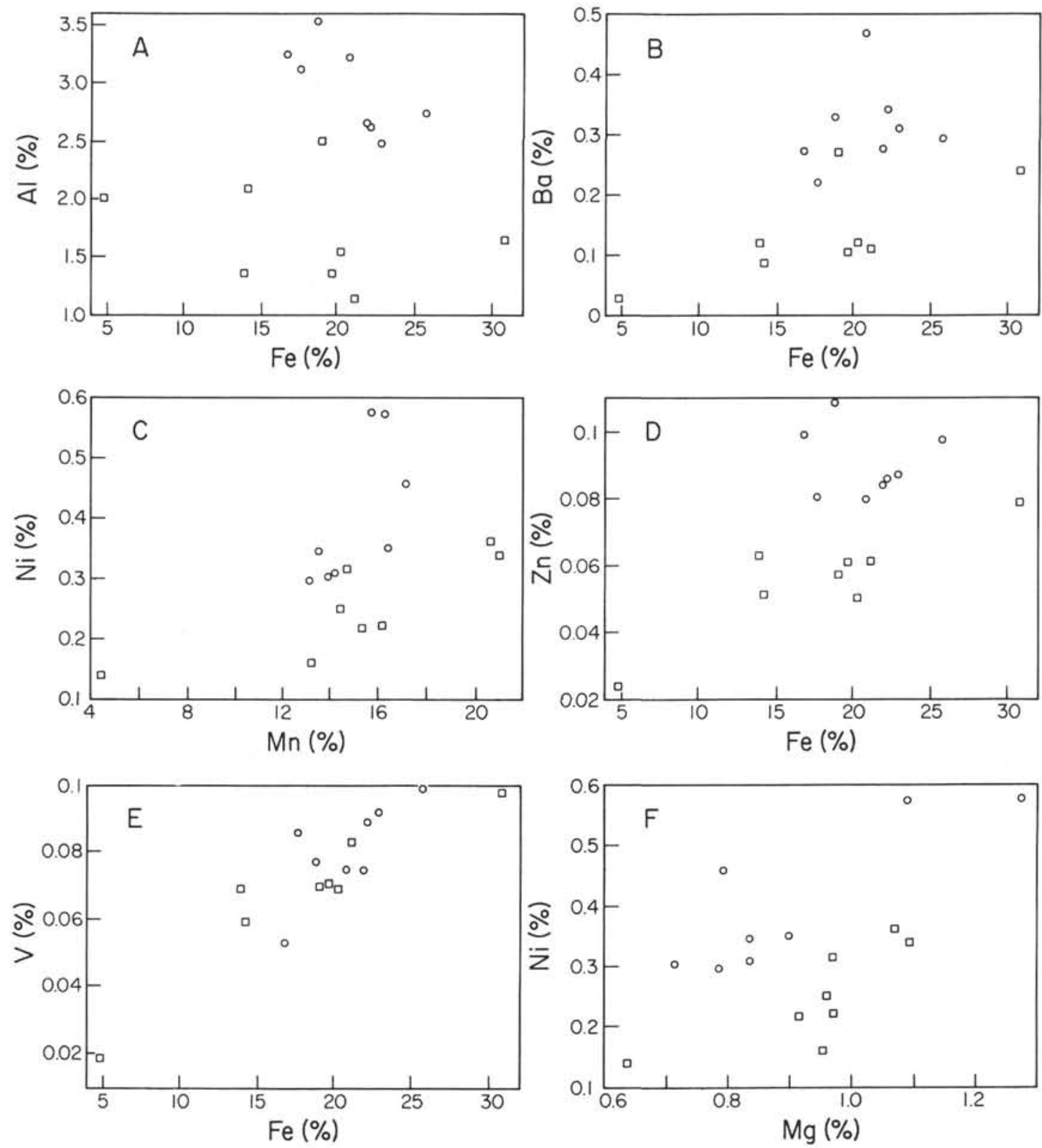

Figure 4. Scatter diagrams of selected elements in Fe-Mn oxides from Wombat Plateau deposits. A. Al vs. Fe. B. Ba vs. Fe. C. Ni vs. Mn. D. Zn vs. Fe. E. V vs. Fe. F. Ni vs. Mg. Squares = BMR dredged samples; circles = ODP core samples.

set. Although the core subset displays strong $\mathrm{Co}$ and $\mathrm{Ni}$ associations with $\mathrm{Mn}$, those of Mo and V with Mn are weaker and negative, respectively. It is possible that burial of the cored Fe-Mn-rich sediments has led to some postdepositional redistribution of these elements that has not occurred in the surface dredged samples.

\section{Rare Earth Elements}

REE concentrations were determined only for the core samples from this study. Individual REE concentrations are presented in Table 4. The data were normalized to the North American Shale Composite (NASC; Haskin et al., 1968) for comparison with REE abundances in other Fe-Mn deposits from the marine environment. The individual normalized REE patterns for each sample are presented in Figure 5. A com- parison of average REE patterns for crusts from the Hawaiian Archipelago (De Carlo et al., 1987a), Kiribati (De Carlo and Fraley, 1990), and samples from this study is given in Figure 6. This figure reveals that Fe-Mn deposits from the study area contain lower concentrations of REE than those in the Hawaiian Archipelago, but display the large positive $\mathrm{Ce}$ anomaly typical of hydrogenous Fe-Mn deposits (De Carlo and Fraley, 1990; De Carlo and McMurtry, in press, and references therein). It is interesting to note that Ce anomalies (see Table 4) observed in this work are significantly greater than in other studies. The greatest $\mathrm{Ce}$ anomaly (7.17) is found for Sample 122-759B-9R-1, 0-3 cm, which displays lower concentrations of the trivalent REE than the samples from Site 760. These findings suggest that this sample may have formed in a highly oxidizing environment that resulted from strong bottom cur- 
Table 4. Rare earth element composition of ferromanganese nodules and crusts.

\begin{tabular}{|c|c|c|c|c|c|c|c|c|c|c|c|c|c|c|c|}
\hline $\begin{array}{l}\text { Core, section, } \\
\text { interval }(\mathrm{cm})\end{array}$ & $\mathrm{La}$ & $\mathrm{Ce}$ & Pr & $\mathrm{Nd}$ & $\mathrm{Sm}$ & $\mathrm{Eu}$ & Gd & $\mathrm{Tb}$ & Dy & Ho & Er & $\mathrm{Tm}$ & $\mathrm{Yb}$ & $\mathrm{Lu}$ & $\begin{array}{c}\mathrm{Ce} \\
\text { anomaly }^{\mathrm{a}}\end{array}$ \\
\hline \multicolumn{16}{|l|}{$122-759 \mathrm{~B}-$} \\
\hline${ }^{b} 9 \mathrm{R}-1,0-3$ & 69 & 2058 & 14.1 & 50.4 & 4.49 & 0.80 & 17.2 & 16.2 & 8.51 & 1.45 & 5.74 & & 3.79 & 0.70 & 7.17 \\
\hline \multicolumn{16}{|l|}{$122-760 \mathrm{~A}-$} \\
\hline $9 \mathrm{H}-5,2-4$ & 122 & 1350 & 22.2 & 90.8 & 13.8 & 1.33 & 21.3 & 11.4 & 14.4 & 2.86 & 9.25 & 1.12 & 7.51 & 1.46 & 2.79 \\
\hline${ }_{9 H}-5,10-13$ & 166 & 1915 & 29.6 & 122 & 18.8 & 3.02 & 27.8 & 16.4 & 17.8 & 3.18 & 10.4 & 1.33 & 8.33 & 1.45 & 2.94 \\
\hline${ }_{9 H-5}, 10-13$ & 154 & 1760 & 27.0 & 118 & 16.1 & 2.24 & 24.6 & 15.6 & 16.4 & 2.90 & 10.8 & & 8.02 & 1.88 & 2.92 \\
\hline${ }^{c} 9 \mathrm{H}-5,20-22$ & 184 & 1925 & 31.6 & 134 & 21.0 & 2.29 & 31.4 & 16.0 & 20.8 & 3.90 & 14.0 & 1.50 & 10.1 & 1.80 & 2.70 \\
\hline $10 X-1,14-16$ & 152 & 1670 & 25.4 & 110 & 14.8 & 2.72 & 25.5 & 16.0 & 17.1 & 3.53 & 12.1 & & 9.57 & 1.69 & 2.87 \\
\hline $11 \mathrm{X}-1,7-9$ (outer) & 159 & 1990 & 27.5 & 114 & 16.7 & 2.56 & 27.8 & 14.4 & 17.0 & 3.01 & 10.7 & 1.32 & 8.02 & 1.48 & 3.23 \\
\hline $11 X-1,7-9$ (inner) & 226 & 2460 & 36.8 & 148 & 18.4 & 3.96 & 35.4 & 18.6 & 22.0 & 4.06 & 14.0 & 1.44 & 11.0 & 1.95 & 2.88 \\
\hline${ }^{\mathrm{N} N A S C}$ & 32 & 73 & 7.9 & 33 & 5.7 & 1.24 & 5.2 & 0.85 & 5.8 & 1.04 & 3.4 & 0.5 & 3.1 & 0.48 & \\
\hline
\end{tabular}

Note: Concentrations expressed in $\mu \mathrm{g} / \mathrm{g}$ solid phase on a $110^{\circ} \mathrm{C}$ dried basis.

${ }^{a}$ Defined as $2\left(\mathrm{Ce} / \mathrm{Ce}^{*}\right) /\left(\mathrm{La} / \mathrm{La}^{*}+\mathrm{Pr} / \mathrm{Pr}^{*}\right)$, where ${ }^{*}$ indicates the shale value.

b Untreated nodule.

c Sediment leached with sodium acetate/acetic acid buffer.

d North American Shale Composite from Haskin et al. (1968).

rents. The proposed Paleocene-Eocene age of this nodule suggests that cold oxidizing water moving northward along western Australia bathed the Wombat Plateau and enhanced the development of highly oxic conditions.

Another feature observed in the REE patterns is a significant positive Gd anomaly that is larger than those previously identified by Hein et al. (1988) in the Marshall Islands and by De Carlo (1990) in a thick Fe-Mn crust from Schumann seamount near the Hawaiian Archipelago. Probably the most unusual feature of the REE patterns in this study is the apparent depletion of the elements Nd, Sm, and Eu in Sample 122-759B-9R-1, 0-3 cm, and to a lesser extent $\mathrm{Sm}$ and $\mathrm{Eu}$ in the other samples relative to their near-neighbor elements $\mathrm{Pr}$ and Gd (Fig. 5). These results are not likely caused by spectral interferences in the ICP technique, and the extent of depletion varies from sample to sample. However, the low concentrations of $\mathrm{Eu}$ in the analyzed solutions does lead to a larger relative error for this element than for many other REE. A slight upward trend for the heavy REE Yb and Lu that can be attributed to the incorporation of apatite (e.g., De Carlo, 1991) in the ferromanganese is unlikely here because no apatite was identified by XRD.

\section{Comparison with Other Marine Fe-Mn Deposits}

A comparison of average elemental abundances in the samples from this study with those of other marine $\mathrm{Fe}-\mathrm{Mn}$ deposits is presented in Table 5. The data in this table indicate that the Wombat Plateau samples (excluding BMR56-DR14-I2 due to its highly anomalous composition) are generally similar to other Fe-Mn deposits from plateau settings in the Australian region. The Mn content is quite consistent throughout the Australian region except for the samples recovered from the Cape Leeuwin nodule field. This is not surprising as these are deep-sea nodules $(4300-5300 \mathrm{~m})$ that resemble deep-sea $\mathrm{Pa}$ cific Ocean deposits more and typically have a much greater abundance of todorokite and hence a higher $\mathrm{Mn} / \mathrm{Fe}$ ratio than the plateau deposits, which tend to be more enriched in vernadite. A greater variability is observed for $\mathrm{Fe}$, and its concentration is more elevated in samples from this study than from other sites such as the Tasman Sea rises, Wallaby Plateau, and Coral Sea. However, both the Scott Plateau and the South Tasman Rise deposits display nearly identical Fe contents to those found here. Metals of potential commercial interest $(\mathrm{Co}, \mathrm{Cu}$, and $\mathrm{Ni})$ exhibit generally quite low concentrations throughout the Australian region (generally below $1 \%$ ) in comparison with the higher average values (near $1.4 \%$ ) found for deep-sea nodules and especially with those of the high-grade $(2.5 \%-3 \%)$ Clarion-Clipperton nodule belt of the north equatorial Pacific Ocean (Cronan, 1980).

The detrital mineral content of the deposits from this study, as measured by their $\mathrm{Al}, \mathrm{Ca}, \mathrm{Mg}, \mathrm{Si}$, and $\mathrm{Ti}$ contents, is in agreement with other studies except that South Tasman Rise deposits display more elevated $\mathrm{Ca}$ and $\mathrm{Al}$ concentrations. No significant differences in the other metals analyzed exist between the samples from this study and the available data in Table 5 .

\section{CONCLUSIONS}

Ferromanganese crusts and nodules from the Wombat Plateau are primarily vernadite-rich deposits with minor amounts of todorokite and goethite. The deposits are characterized by a low $\mathrm{Mn} / \mathrm{Fe}$ ratio (average $=0.77$, range $=$ $0.43-1.05$ ) and exhibit relatively low concentrations of the transition metals of potential commercial interest $(\mathrm{Co}+\mathrm{Cu}+$ $\mathrm{Ni}=0.68 \%$ ). They are quite similar to other plateau Fe-Mn crusts and nodules from the Australian region and are of no commercial interest.

The results of microscopic examination of the calcareous organisms in the sediments, crusts, and nodules cored during Leg 122 suggest that they formed in the Late Cretaceous to Eocene. Samples recovered during BMR cruise 56 may have begun to accumulate as early as the Late Cretaceous and ferromanganese oxide accumulation is likely to have continued through the present.

Rare earth elements in the ODP core samples generally exhibit lower concentrations than those in Pacific seamount $\mathrm{Fe}-\mathrm{Mn}$ crusts but are characterized by high $\mathrm{Ce}$ anomalies. The highest $\mathrm{Ce}$ anomaly (7.17) and lowest REE abundances were observed in Sample 122-759B-9R-1, 0-3 cm. These findings suggest that this sample may have formed under extremely oxidizing conditions enhanced by the presence of strong bottom currents.

\section{ACKNOWLEDGMENTS}

We are grateful to the captains and crews of Rig Seismic and JOIDES Resolution for their assistance at sea. We also express our appreciation to the co-chief scientists of the cruises as well as to our shipboard colleagues. Technical assistance was provided by D. Koeppenkastrop, W. Shibata, and K. Mitchell. Ulrich von Rad provided photographs and lithologic descriptions of the Rig Seismic dredge samples. We acknowledge reviews by V. Marchig and D. Puteanus-Stube 


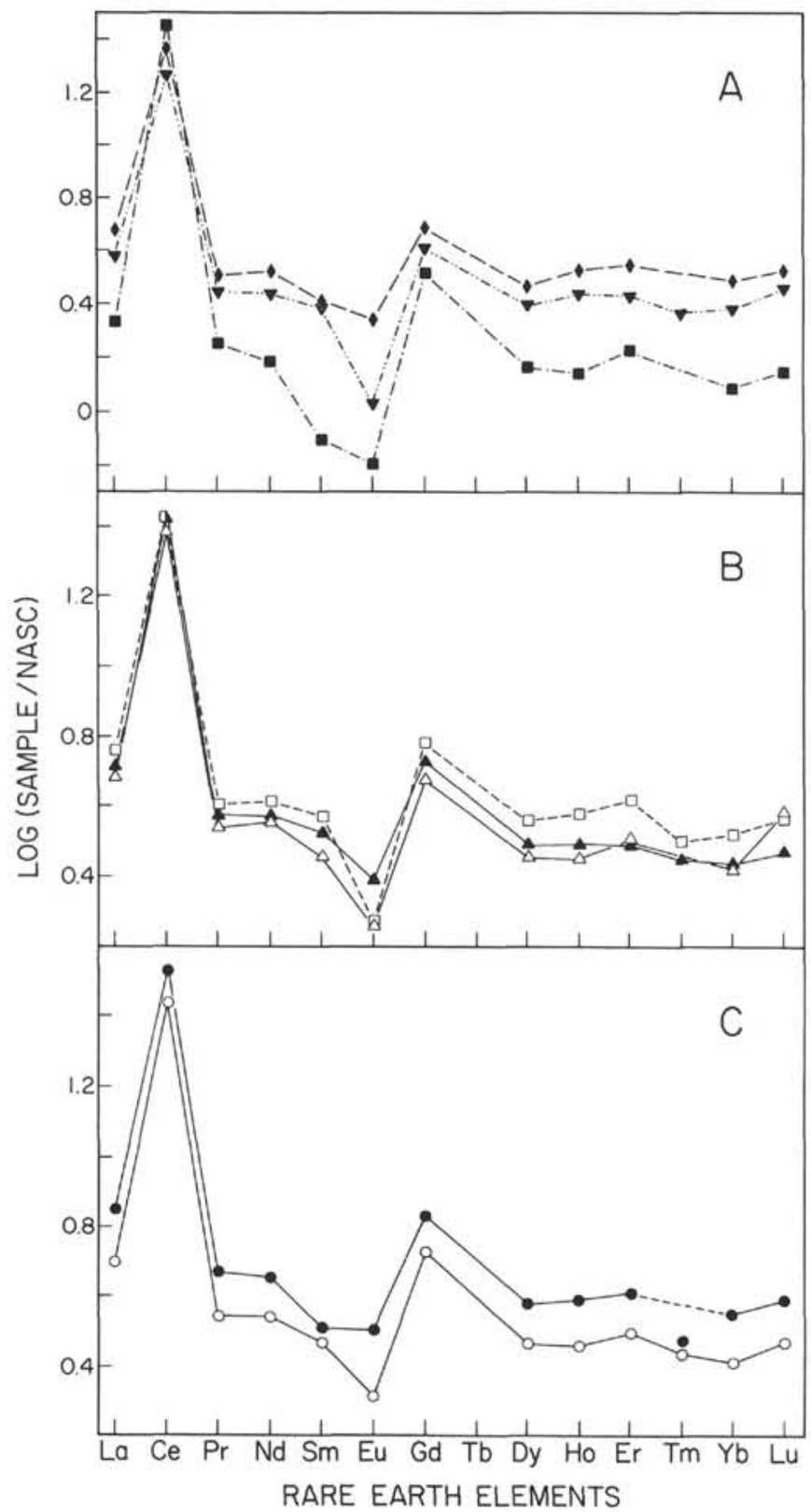

Figure 5. Shale-normalized REE patterns of Fe-Mn-rich samples from the Wombat Plateau. A. Squares = Sample 122-759B-9R-1, 0-3 cm; triangles $=$ Sample $122-760 \mathrm{~A}-9 \mathrm{H}-5,2-4 \mathrm{~cm}$; and diamonds $=$ Sample $122-760 \mathrm{~A}-10 \mathrm{X}-1,14-16 \mathrm{~cm}$. B. Open triangles $=$ Sample $122-760 \mathrm{~A}-$ $9 \mathrm{H}-5,10-13 \mathrm{~cm}$ (SASED); solid triangles = Sample 122-760A-9H-5, $10-13 \mathrm{~cm}$ (NOD); and squares = Sample 122-760A-9H-5, 20-22 cm (SASED). C. Inner (solid symbols) and outer (open symbols) portions of Sample 122-760A-11X-1, 7-9 cm. SASED is sodium acetate/acetic acid buffer leached sediment, NOD is an untreated nodule.

which greatly improved this manuscript. Research support to E. De Carlo was provided through a U.S. Science Advisory Committee (USSAC) ODP post-cruise grant. N. Exon publishes with the permission of the Director, Bureau of Mineral Resources, Canberra. Any opinions, findings and conclusions or recommendations expressed in this publication are those of the authors and do not necessarily reflect the views of the National Science Foundation, Joint Oceanographic Institutions, Inc., or Texas A\&M University. This is SOEST contribution no. 2394.

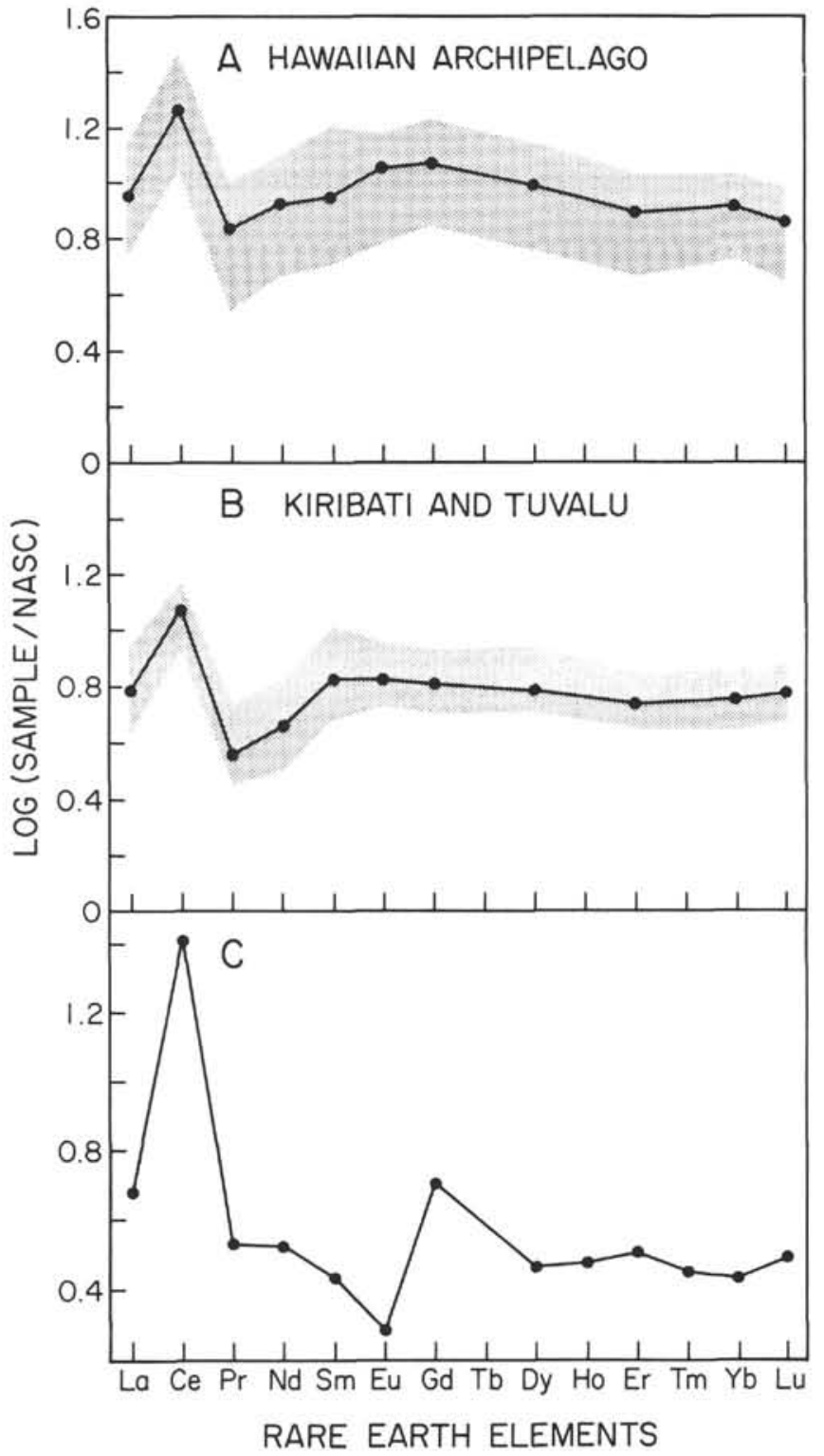

Figure 6. Comparison of shale-normalized average REE abundance patterns for marine Fe-Mn deposits. A. Average and range of crusts from the Hawaiian Archipelago (De Carlo et al., 1987a). B. Average and range of crusts from Kiribati (De Carlo and Fraley, 1990). C. Average of crusts from this study of the Wombat Plateau.

\section{REFERENCES}

Aplin, A. C., and Cronan, D. S., 1985a. Ferromanganese oxide deposits from Central Pacific Ocean. I: Encrustations from the Line Island Archipelago. Geochim. Cosmochim. Acta, 49:427436.

1985b. Ferromanganese oxide deposits from the Central Pacific Ocean. II: Nodules and associated sediments. Geochim. Cosmochim. Acta, 49:437-451.

Bolton, B. R., Bogi, J., and Cronan, D. S., 1990. Geochemistry and mineralogy of ferromanganese nodules from the Kiribati region of the eastern Central Pacific. In Keating B., and Bolton, B. (Eds.), Geology and Offshore Mineral Resources of the Central Pacific Basin. Circum Pacific Council for Energy and Mineral Resources, Earth Sci. Ser., 15:247-260.

Bolton, B. R., Exon, N. F., Ostwald, J., and Kudrass, H. R., 1988. Geochemistry of ferromanganese crusts and nodules from the South Tasman Rise, southeast of Australia. Mar. Geol., 84:53-80. 
Burns, R. G., and Burns, V. M., 1977. Mineralogy. In Glasby, G. P. (Ed.), Marine Manganese Deposits: Amsterdam (Elsevier), 185248.

Cook, P. J., 1977. Mesozoic-Cenozoic sediments of the eastern Indian Ocean. In Heirtzler, J. R., Bolli, H. M., and Davies, T. A. (Eds.), Indian Ocean Geology and Biostratigraphy: Washington (Am. Geophys. Union), 119-150.

Craig, J. D., Andrews, J. E., and Meylan, M. A., 1982. Ferromanganese deposits in the Hawaiian Archipelago. Mar. Geol., 45:127-157.

Cronan, D. S., 1980. Underwater Minerals: London (Academic Press).

De Carlo, E. H., 1990. Separation of lanthanide series elements in marine $\mathrm{Fe}-\mathrm{Mn}$ crusts by ion-exchange chromatography and determination by ICP/AES. Sep. Sci. Technol., 25:781-798.

1991. Paleoceanographic implications of intrasample rare earth element variability within a $\mathrm{Fe}-\mathrm{Mn}$ crust from the central Pacific Ocean. Mar. Geol., 98.

De Carlo, E. H., and Fraley, C., 1990. Chemistry and mineralogy of ferromanganese deposits from the south Equatorial Pacific Ocean. In Keating B., and Bolton, B. (Eds.), Geology and Offshore Mineral Resources of the Central Pacific Basin. Circum Pacific Council for Energy and Mineral Resources, Earth Sci. Ser., $15: 225-245$.

De Carlo, E. H., and McMurtry, G. M., in press. Rare earth element geochemistry of ferromanganese deposits from the Hawaiian Archipelago. Chem. Geol.

De Carlo, E. H., McMurtry, G. M., and Kim, K. H., 1987a. Geochemistry of ferromanganese crusts from the Hawaiian Archipelago-I. Northern survey areas. Deep-Sea Res. Part A, 34:441-467.

De Carlo, E. H., Pennywell, P. A., and Fraley, C. M., 1987b. Geochemistry of ferromanganese deposits from the Kiribati and Tuvalu Region of the West Central Pacific Ocean. Mar. Min., 6:301-321.

Exon, N. F., 1982. Manganese nodules in the Kiribati region, Equatorial Western Pacific. South Pac. Mar. Geol. Notes, 2:77-102.

Exon, N. F., Cronan, D. S., and Colwell, J. B., in press. New developments in manganese nodule prospects, with emphasis on the Australasian region. Proc. Pac. Rim Congr.

Exon, N. F., and Willcox, J. B., 1980. The Exmouth Plateau: stratigraphy, structure and petroleum potential. Bull. Bur. Miner. Resour. Geol. Geophys. Aust., 199.

Exon, N. F., and Williamson, P. E., 1988. Preliminary post-cruise report, Rig Seismic research cruises 7 \& 8: sedimentary basin framework of the northern and western Exmouth Plateau. Bur. Min. Resour. Aust. Rec., 1988/30.

Flanagan, F. J., and Gottfried, D., 1980. USGS rock standards, III: manganese nodule reference samples USGS-Nod-A1 and USGSNod-P1. Geol. Surv. Prof. Pap. U.S., 1155.

Glasby, G. P., 1977. Marine Manganese Deposits: Elsevier Oceanogr. Ser., 15:1-523.

Halbach, P., and Manheim, F. T., 1984. Potential of cobalt and other metals in ferro-manganese crusts on seamounts of the Central Pacific Basin. Mar. Min., 4:319-336.

Halbach, P., Manheim, F. T., and Otten, P., 1982. Co-rich ferromanganese deposits in the central seamount regions of the Central Pacific Basin-results of the Midpac '81. Erzmetall, 35:447-453.

Halbach, P., and Ozkara, M., 1979. Morphological and geochemical classification of deep-sea ferromanganese nodules and its genetical interpretation. In Lalou, C. (Ed.), La Genèse des Nodules de Manganèse. Colloq. Int. C.N.R.S., 289:77-88.

Halbach, P., and Puteanus, D., 1984. Influence of the carbonate dissolution rate on the growth and composition of Co-rich ferromanganese crusts from Central Pacific seamount areas. Earth Planet. Sci. Lett., 68:73-87.
Halbach, P., Segl, M., Puteanus, D., and Mangini, A., 1983. Co-fluxes and growth rates in ferromanganese deposits from Central Pacific seamount areas. Nature, 304:716-719.

Haskin, L. A., Haskin, M. A., Frey, F. A., and Wildeman, T. R., 1968. Relative and absolute terrestrial abundances of the rare earths. In Ahrens, L. H. (Ed.), Origin and Distribution of the Elements: Oxford (Pergamon), 889-911.

Haq, B. U., von Rad, U., O'Connell, S., et al., 1990. Proc. ODP, Init. Repts., 122: College Station, TX (Ocean Drilling Program).

Hein, J. R., Manheim, F. T., Schwab, W. C., and Davis, A. S., 1985a. Ferromanganese from Necker Ridge, Horizon Guyot and S. P. Lee Guyot: geological considerations. Mar. Geol., 69:25-54.

Hein, J. R., Manheim, F. T., Schwab, W. C., Davis, A. S., Daniel, C. L., Bouse, R. M., Morgenson, L. A., Sliney, R. E., Clague, D., Tate, G. B., and Cacchione, D. A., 1985b. Geological and Geochemical Data for Seamounts and Associated Ferromanganese Crusts In and Near the Hawaiian, Johnston Island, and Palmyra Island Exclusive Economic Zones. Open-File Rep.-U.S. Geol. Surv., 85-292.

Hein, J. R., Schwab, W. C., and Davis, A. S., 1988. Co- and Pt-rich ferromanganese crusts and associated substrate rocks from the Marshall Islands. Mar. Geol., 78:255-283.

Hinz, K., Beiersdorf, H., Exon, N. F., Roeser, H. A., Stagg, H.M.J., and von Stackelberg, U., 1978. Geoscientific investigations from the Scott Plateau off northwest Australia to the Java Trench. BMR J. Aust. Geol. Geophys., 3:319-340.

Jones, H. A., 1980. Deepsea manganese nodules in the Australian region: a review. Aust. Miner. Ind. Q., 33:1-14.

Kingston, H. M., and Jassie, L. B., 1986. Microwave energy for acid decomposition at elevated temperatures and pressures using biological and botanical samples. Anal. Chem., 58:2534-2541.

Ludden, J. N., Gradstein, F. M., et al., 1990. Proc. ODP, Init. Repts., 123: College Station, TX (Ocean Drilling Program).

Meylan, M. A., Glasby, G. P., and Fortin, L., 1981. Bibliography and Index to Literature on Manganese Nodules (1861-1979): Honolulu (State of Hawaii, Dept. of Planning and Econ. Dev.).

Nadkarni, R. A., 1984. Applications of microwave oven sample dissolution in analysis. Anal. Chem., 56:2233-2237.

Ostwald, J., 1988. Mineralogy of the Groote Eylandt manganese oxides: a review. Ore Geol. Rev., 4:3-45.

Pettis, R. W., and de Forest, A., 1979. Chemical deposition of ferromanganese nodules from the Southern Ocean. Aust. J. Mar. Freshwater Res., 30:535-539.

Pichoki, C., and Hoffert, M., 1987. Characteristics of Co-rich ferromanganese nodules and crusts sampled in French Polynesia. Mar. Geol., 77:109-119.

von Stackelberg, U., 1978. A polygenetic manganese nodule from the Scott Plateau off northwest Australia. BMR J. Aust. Geol. Geophys., 3:349-350.

von Stackelberg, U., Exon, N. F., von Rad, U., Quilty, P., Shafik, S., Beiersdorf, H., Seibertz, E., and Veevers, J. J., 1980. Geology of the Exmouth and Wallaby plateaus off northwest Australia: sampling of seismic sequences. BMR J. Aust. Geol. Geophys., 5:113140.

von Stackelberg, U., Kunzendorf, H., Marchig, V., and Gwodz, R., 1984. Growth history of a large ferromanganese crust from the equatorial North Pacific nodule belt. Geol. Jahrb., A75:213-235.

Date of initial receipt: 18 April 1990

Date of acceptance: 19 February 1991 Ms 122B-183 
Table 5. Summary of the elemental composition (weight \%) of ferromanganese nodules and crusts from the Australian region.

\begin{tabular}{|c|c|c|c|c|c|c|c|c|c|}
\hline $\begin{array}{l}\text { Location } \\
\text { (water } \\
\text { depth, m) }\end{array}$ & $\begin{array}{l}\text { This study }{ }^{a} \\
(2690-4600)\end{array}$ & $\begin{array}{c}\text { South Tasman } \\
\text { Rise }^{\mathrm{b}} \\
(1600-4000)\end{array}$ & $\begin{array}{c}\text { Tasman Sea } \\
\text { rises }^{c} \\
(1550-2530)\end{array}$ & $\begin{array}{l}\text { Cape Leeuwin } \\
\text { deep-sea } \\
\text { nodule field } \\
(4300-5300)\end{array}$ & $\begin{array}{l}\text { Pacific Ocean } \\
\text { average }^{\mathrm{e}}\end{array}$ & $\begin{array}{l}\text { Indian Ocean } \\
\text { average }^{e}\end{array}$ & $\underset{\substack{\text { Plateauf } \\
(1933-2587)}}{\text { Scott }}$ & $\begin{array}{c}\text { Wallaby } \\
\text { Plateaug } \\
(2500-4300)\end{array}$ & $\begin{array}{l}\text { Coral Sea }{ }^{\mathrm{h}} \\
(978-2555)\end{array}$ \\
\hline $\mathrm{Mn}$ & 15.77 & 15.01 & 14.66 & 20.3 & 19.78 & 15.10 & 18.2 & 12.92 & 13.8 \\
\hline $\mathrm{Fe}$ & 20.45 & 19.22 & 12.92 & 11.9 & 11.96 & 14.74 & 18.5 & 12.83 & 13.1 \\
\hline $\mathrm{Ni}$ & 0.34 & 0.39 & 0.39 & 0.94 & 0.63 & 0.46 & 0.38 & 0.29 & 0.26 \\
\hline $\mathrm{Cu}$ & 0.12 & 0.16 & 0.31 & 0.28 & 0.39 & 0.29 & 0.05 & 0.11 & 0.06 \\
\hline Co & 0.22 & 0.33 & 0.27 & 0.12 & 0.33 & 0.23 & 0.33 & 0.17 & 0.29 \\
\hline $\mathrm{Ni}+\mathrm{Cu}+\mathrm{Co}$ & 0.68 & 0.88 & 0.97 & 1.34 & 1.35 & 0.98 & 0.76 & 0.57 & 0.62 \\
\hline $\mathrm{Zn}$ & 0.08 & 0.08 & 0.14 & 0.08 & 0.07 & 0.07 & & & \\
\hline $\mathrm{Pb}$ & - & 0.14 & 0.14 & 0.06 & 0.08 & 0.09 & & & \\
\hline $\mathrm{Si}$ & 8.01 & 9.51 & 10.72 & - & 8.32 & 11.40 & & & \\
\hline Al & 2.35 & 5.66 & 2.65 & 2.13 & 3.06 & 2.49 & & & \\
\hline $\mathrm{Ti}$ & 0.73 & 0.71 & 0.53 & 0.46 & 0.67 & 0.66 & & & \\
\hline $\mathrm{Mg}$ & 0.94 & 1.41 & 1.50 & 1.66 & 1.71 & - & & & \\
\hline $\mathrm{Ca}$ & 1.68 & 3.74 & 1.74 & 1.23 & 1.96 & 2.37 & & & \\
\hline $\mathrm{Na}$ & - & 0.49 & 0.34 & - & 2.05 & - & & & \\
\hline K & - & 0.73 & 0.43 & 0.29 & 0.75 & - & & & \\
\hline$P$ & - & 1.05 & 0.41 & - & 0.23 & - & & & \\
\hline $\mathrm{Ba}$ & 0.24 & - & - & 0.03 & 0.28 & 0.18 & & & \\
\hline V & 0.08 & - & - & 0.04 & 0.05 & 0.04 & & & \\
\hline Mo & 0.028 & - & - & 0.03 & 0.04 & 0.03 & & & \\
\hline
\end{tabular}

${ }^{\text {a }}$ Fifteen nodule and crust samples.

b Eighteen nodule and crust samples (Bolton et al., 1988).

c Four nodule and crust samples (Bolton et al., 1990).

Seven nodule samples (Pettis and de Forest, 1979).

e Cronan (1980).

${ }^{f}$ Eight nodule and crust samples (Hinz et al., 1978).

g Thirty-three nodule and crust samples (von Stackelberg et al., 1980).

${ }^{\mathrm{h}}$ Six nodule and crust samples (Exon et al., in press). 